\title{
TRADITIONAL ECONOMIC PHILANTHROPY: EVIDENCE FROM MADURESE ALTRUISM LOCAL PATTERN
}

\author{
Prasetyono, Yuliana Rakhmawati, Erfan Muhammad, Emi Rahmawati, and Ach Fawaiq As'ad \\ Universitas Trunojoyo Madura, Bangkalan, Indonesia, Jl. Raya Telang Po. Box. 02 Kamal Bangkalan \\ E-mail: prasetyono_akt@trunojoyo.ac.id; yuliana.r@trunojoyo.ac.id; erfan94@yahoo.com, \\ emi.rahmawati@trunojoyo.ac.id, fhawaid01@gmail.com
}

\begin{abstract}
Recently, modern philanthropy practices tends to relate with corporations, organizations, and institutions activities. Meanwhile in some Indonesia's regions, philanthropy is not always present in that context. Madura is one of the regional that traditionally uses philanthropic patterns in its economic activities as social and cultural traits and custom. Therefore, this research attempt to describe the traditional philanthropy in Madurese. This research uses qualitative perspective and employed Interpretive Phenomenological Analysis (IPA) to gain the local perspective experience and meaning construction in traditional philanthropy through cattle sharing program. Parties involve in this research are the breeders or cattle farmers and local investors. The research found that Madurese traditional economic philanthropy activities are carried out in a cattle sharing practice with local wisdom principle. Madurese local philanthropy pattern has the context of reducing breeding risk or loss if the cattle are sicks or death. These activities seem to be quite helpful in strengthening the helping spirit and strengthening the local traits and customs economy. Hence, by conducting the value of tolong bi nolong local people tends to practice philanthropic engagement. The future studies could explore more culturally and institutionally structured management to enhance this good practice sustainability.
\end{abstract}

Key words: Cattle sharing; Philanthropy; Local wisdom; IPA

\section{FILANTROPI EKONOMI TRADISIONAL: POLA ALTRUISME LOKAL MADURA}

\begin{abstract}
ABSTRAK. Dewasa ini, praktik filantropi modern cenderung berhubungan dengan kegiatan korporasi, organisasi, dan institusi. Sementara itu, filantropi di Indonesia tidak selalu hadir dalam konteks itu. Madura adalah salah satu daerah yang secara tradisional menggunakan pola filantropis dalam kegiatan ekonominya sebagai ciri sosial budaya dan adat istiadat. Penelitian ini mencoba mendeskripsikan filantropi tradisional dalam sistem gaduhan sapi masyarakat Madura. Penelitian ini menggunakan perspektif kualitatif dan menggunakan Interpretive Phenomenological Analysis (IPA) untuk mendapatkan perspektif lokal dalam pengalaman dan memberi makna dalam filantropi tradisional melalui program gaduhan sapi. Pihak yang terlibat dalam penelitian ini adalah para peternak dan investor lokal. Hasil penelitian menemukan bahwa kegiatan filantropi ekonomi tradisional masyarakat Madura dilakukan dalam praktik berbagi ternak dengan prinsip kearifan lokal. Pola filantropi lokal Madura memiliki konteks untuk mengurangi risiko pengemukan atau kerugian jika sapi sakit atau mati. Kegiatan-kegiatan tersebut nampaknya cukup membantu dalam memperkuat semangat menolong dan memperkuat ciri-ciri lokal dan ekonomi tradisional. Tolong menolong yang dilakukan peternak sapi di Madura dalam mengurangi risiko kerugian karena sapi sakit. Karenanya, dengan melakukan nilai tolong bi nolong, masyarakat setempat cenderung melibatkan praktik filantropi. Studi filantropi kedepan dapat mengeksplorasi manajemen yang lebih terstruktur secara budaya dan kelembagaan untuk meningkatkan praktik keberlanjutan yang baik ini.
\end{abstract}

Kata kunci: Gaduhan; Filantropi; Kearifan Lokal; IPA

\section{INTRODUCTION}

Indonesian are familiar with altruism as the "golden rules" value and concept since ancient times (Latief, 2010). The altruism pattern and practice are implemented in the social life within the aspects of economy (Sakni, 2013; Tamim, 2016); education (Nasrullah, 2015); religious institutions (Abida, 2016); arts and culture (Sumrahadi \& Suryandari, 2013); disaster mitigation (Sitorus, 2013). The altruism practice development mainstreaming in the form of philanthropy towards social justice was also initiated (Fauzia, 2017), even more influential in institutions and corporations (Jusuf, 2007; Makhrus, 2014; Prananingrum, 2018).
The development of modern philanthropic practices in Indonesia also tends to traditional practices in local communities. In Madura, the practice of beef cattle sharing is a form of philanthropy in the economic field. The practice of partnership patterns in cattle in Indonesia includes partnerships that produce calves, feeder cattle and ready-to-be beef cattle (Tawaf, 2018). The cattle sharing system in Madura has its uniqueness compared to other areas in Indonesia (Djaelani et al., 2009); Ibrahim et al., 2013; Novra, 2015). The cattle sharing practice sustains the identity of Madura as the cattle producer in Indonesia.

Madura is geographically divided into two parts: West - Bangkalan and Sampang, and East - 
Pamekasan and Sumenep (BPS-Statistic Indonesia, 2018). The society in West Madura knows the cattle sharing as "raksaan", while the people in the east call it "oanan". The attachment of culture and local wisdom influences the cattle sharing practice by the Madurese. The Madurese practices and values the local wisdom differently (Prasetyono \& Rakhmawati, 2019). This statement follows Suharto (2015) that the traditional social protection system in Indonesia is formed from the safety net of families and communities and has proven to be unable to adapt to the demands of a liberal market economy. The preservation of traditional and local values in the noise of the Madurese cows is because the community places more emphasis on religious, familial, social and mutual values in their lives than business values. The different motivations and goals of the cattlemen cause various motivations in breeding the cattle, such as cows as cattle commodities (Hartatik et al., 2009; Nurgiartiningsih, 2011; Efendy, 2016; Kutsiyah, 2018); ornamental cow (Kutsiyah, 2019), and cow racing (Kosim, 2007; Riszqina et al., 2014).

As business practices, the cattle stakeholders also own economic interests. Economic motivation, profit-oriented undeniably becomes the main goal of the cattle stakeholders. In addition to the profit aspect, the stakeholders need to consider the possible risk during the collaboration. Business risk is an aspect that needs to be taken into respective consideration by business actors (Ang et al., 1995; Lavington, 1925; Sarasvathy et al., 1998;. Scott, 2004). Madurese, in this case is the stakeholders, are aware of the possible risks as they do risk mitigation hereditary with the formula that the society agreed together on.

The mitigation done by the traditional entity in business risk resolution sometimes prioritizes the value of local wisdom (Kantabutra \& Suriyankietkaew, 2019; Nurhayati et al., 2016; Prasetyo et al., 2015; Suartana \& Jati, 2017). The cattlemen in Madura undergo the risk mitigation which is known as "tolong bi nolong". The concept of the business risk might against the modern risk management (Hoyt \& Liebenberg, 2011; Kumar et al., 2010; Wu et al., 2015; Wüllenweber et al., 2008). Nevertheless, the local wisdom "tolong bi nolong" that comes with parsimony, the society of cattle sharing in Madura can sustain in this business. The dynamic of the running business uses philanthropy approaches by prioritizing brotherhood as an investment.

The persuasion in this business practice resembles the diverse traditional philanthropy practices in some regions in Indonesia. Working hand-in-hand (Bowen, 1986), sharing awareness among Batak people (Kurniawan, 2016); Indonesian culturally performs it through youth organization (Atika, 2017). There is a wide range of philanthropy activities potential within local society in Indonesia, no wonder Indonesia is empirically named as the most ten generous country in the world (Charities Aid Foundation, 2019). The involvement of local value in philanthropy practice makes the traditional pattern interesting to explore as academic references and best practices for a sustainable management.

This article describes within the awareness point of view upon the motivation and meaning of cattle sharing in Madura. The cattlemen farmer as the sharer and the local investor as the owner of the cattle are the actors that will explain their experiences around traditional philanthropy practices. The business system of this context does not turn out merely as profit oriented, but also the local wisdom upholding. The business becomes the catalyst for the economic strengthening and life sustainability of society. The moderation is an exciting study for further investigation from various perspectives. Financial perspective and local wisdom are the attractive objects of the traditional philanthropy study.

\section{Economic of Altruism: Moral Obligation or Philanthropy Practices?}

Altruism discussion is inseparable from moral philosophy which became a dynamic discourse in the medieval era by Thomas Hobes, known as the theory of empirical morality. As a terminology, the academics agreed on altruism as a concept that contains moral rules. This context has left a room for discussion about the aspect and value of ontology as an essence or empirical practice. Some scientists formally study philanthropy within the perspective of economic (Monroe, 1996), psychology, sociology (Scott \& Seglow, 2007).

In market economy mechanism, altruism is considered to be potential in breaking through the competition failure and creating market efficiency (Kolm, 2006). The efficient market competition is formed due to the social condition that appears as the power of trust altruism (Lipset, 1996; Wuthnow, 1991). On the other hand, society considered the existence of altruism values and norms as part of getting the reciprocity of their importance (Adloff, 2009). This includes altruism done by individuals also institutions through organizations, foundations, and corporations. An entity that carries out altruism practice with a charity to other society means that institutionalizing, charism, and the public good (Adloff, 2014; Barman, 2017; Kolm, 2006). Those three points are the reciprocity of social 
activity (altruism entity) that public does. Within the institution context, the pattern is considered reasonable because it is related to public trust for the fundraising interest that is intended for donation and social activities (Alexander, 1996).

Since the 19th century, Germany and United States had learned about altruism from the historicalsociological perspective. The studies result in the description of the principle of altruism institutional i.e., institutionalize, charisma principle, related to pubic good, and social group principle (Adloff, 2014). During the development process, the pattern of altruism moral value became the donation practice which then known as philanthropy. With the altruism spirit, philanthropy became a practical manifestation in a more diverse form. This development is inseparable from the role of the entity as a caring reaction of human being's conditions. Non-Governmental Organization (NGO) roundly conducted philanthropy activities such as social activity to build public trust (Adloff, 2016). Within the economic mechanism, the philanthropy value implicitly acts as the indicator of performance attitude on individuals, organizations, foundations, and also corporations (Hammack \& Anheier, 2013).

Many Americans implemented philanthropy as altruism practice as a form of individual charity for public interest (Barman, 2017). The scope and coverage of philanthropy practice then develop and reach other places than the United States, even throughout the world (McGoey, 2015). Philanthropy is also supported by academic studies such as economic, psychology, and anthropology (Andreoni \& Payne, 2013; Lehmann \& Keller, 2006; Piliavin \& Charng, 1990). Recently, sociology studies also work to learn more about philanthropy to contribute knowledge to social interest (Adloff, 2016). Numerous philanthropy studies will motivate individuals, organizations, foundations as well as corporations in donating money and other forms to support social welfare (Barman, 2016).

Today, philanthropy activities synergize with the economic aspects, so the value of altruism develops in more diverse platforms (Kolm, 2006). Many corporations and other institutions attend philanthropic institutional practices in the form of corporate philanthropy. The philanthropic pattern carried out by corporations and other institutions are accommodated in the Corporate Social Responsibility (CSR) activities. The institutional altruism mechanism involves corporations employees, social activities, and volunteer programs (Barman, 2017). In corporations, CSR practices can become obligations in the triple bottom line concept, which includes people, planet, and profit (Marrewijk, 2003; Sherman, 2012). However, in the market mechanism, the CSR of corporations could be one of the solutions to overcome market failure (Barman, 2016). Business ethics has put CSR as the implementation of corporate philanthropy as a form of social responsibility (Tilcsik \& Marquis, 2013). The modern market sees the tendency of the greater characteristics a company has, the higher the propensity to share and do philanthropy (Gautier \& Pache, 2013). CSR is mandatory and at the same time volunteer in public participation and direct reciprocity from market activities (Simpson \& Willer, 2015), as a strategy in inefficient market conditions (Barman, 2017).

Although philanthropy is constantly developing and able to synergized with empirical dynamics and technology, it always leaves room to review from the perspective of altruism spirit. The more entities involved in diverse platforms that accompany it, the higher the various possible motives that become intentions (Adloff, 2009; Edmondson \& Carroll, 1999; Prince et al., 1993). Although there is noempirical studies that give logical inference on motives linearity with philanthropy performance, both in the context of religiosity and the practice of public donations, yet (Collins, 2013; Helms \& Thornton, 2012; Mattis et al., 2000).

Some previous researches shows that traditional philanthropy attempt in various practices. The practice of philanthropy in traditional societies tends to be clandestine (Tamim, 2016), more diverse, and influenced by different demographic, geographical, and other locus of studies (Adloff, 2014). The occurrence of philanthropic patterns in traditional societies is based on religious, psychological values, and tends to be carried out individually as well as initiated by traditional philanthropic and Islamic institutions, such as mosques and Islamic boarding schools (Sulaiman et al., 2018).

However, this research attempts to describe the occurance of philanthropy in Madurese traditional economy activities. These pattern revealed the contribution of philanthropy in empowering societies with enhance the indigeneous wisdom. Traditional merely to traits and customs embedded in Madurese cattle sharing system provide the adequate description about this philanthropy practices. Morever, this also provide the risk likelihood and severity of economic activity in philanthropy spirit.

\section{METHOD}

This study used a qualitative research design. The Approach of this study employed Interpretive 
Phenomenological Analysis (IPA) to gain experience and meaning from stakeholders perspectives (Smith et al., 2011). This study used the general IPA phase. First, choosing a theme that fits the phenomenon. Second, set the research objective. In this study, IPA tends to focus on the experience and knowledge of the stakeholders about certain phenomena. The third was defining sampling from the population with theoretical consistency with qualitative paradigms in general, and oriented towards IPA in particular. The participants were chosen as they could give access to the researcher towards particular perspectives about the researched phenomena. Which means they 'represent' the perspectives, not the population. The subject of the research are the cattle sharing actors which refer to cattle farmer, local investor, and other parties involved (paneggu). The fourth phase, choosing a suitable method to collect data.

The data of this study were collected through detailed stories, thoughts, and feelings of the participants. Therefore, the data of this study were collected by utilizing in-depth interview with semistructured interview, from one participant to another. This is the best method in collecting the data (Reid et al., 2005). Interview allows the researcher and participants to be involved in a dialogue. The researcher could deepen the questions based on the answers the participants gave which were interesting enough to be learned. The fifth phase was setting on particular analysis, directing the attention on the analysis based on the experience and knowledge of cattle sharing system.

\section{RESULTS AND DISCUSSION}

\section{Madura Cattle Sharing: Local Traits and Customs Economy}

Indonesians assume philanthropy as part of their local values transmitted from the ancestors. Indonesians implemented various philanthropy in their daily life in old-fashioned ways. Indonesian's ancestors in Madura had developed similar philanthropy social activity in cattle sharing system tradition (Prasetyono \& Rakhmawati, 2019). The cattle sharing tradition bridges the economic philanthropy in business terminology where profit and loss sharing management is carried out with the principle of helping fellow investors (cattle owners) and cattle farmers (sharer).

Philanthropy tradition tolong bi nolong in cattle sharing by Madurese aims at the interest of all parties. Madura cattle sharing has a unique side that walks side by side with economic and social dimensions (Prasetyono \& Rakhmawati, 2019). Stakeholders take a social part to help the farmers with low income. Philanthropy tradition dimension tolong bin olongin cattle sharing activities also impacts the economic and social aspects. With the economic benefits, it is hoped that economic independence will grow, namely that farmers can utilize their potential to meet their needs and choices in life (Malta, 2016). However, the practice of rowdy cows can economically lead to advantages and disadvantages for farmers and financiers. Meanwhile, the social aspect impacts on working hand-in-hand when run into loss due to cattle sharing activity.

The cattle sharing in Madura which is known as "oanan" has a unique and different sharing pattern than other areas. Local economic activities involved first party, the cattle owner, and the second party, the sharer. Usually, the local characteristics that underlie the basis of the agreement between them are honesty integrity, which honestly is as a cattle sharing livestock in Madura. The Madurese proverb about working hand in hand says "Oreng jujur bakal pojur; oreng pojur mate ngonjur". This is meant to someone that is known of his honesty in socializing and maintain the trust of others in himself. Literally, it means "honest people will get lucky and will die in peace". The local values of this culture become the foundation of Madurese who uphold the values of local wisdom since their ancestors were close to Islamic teachings and cultural traditions.

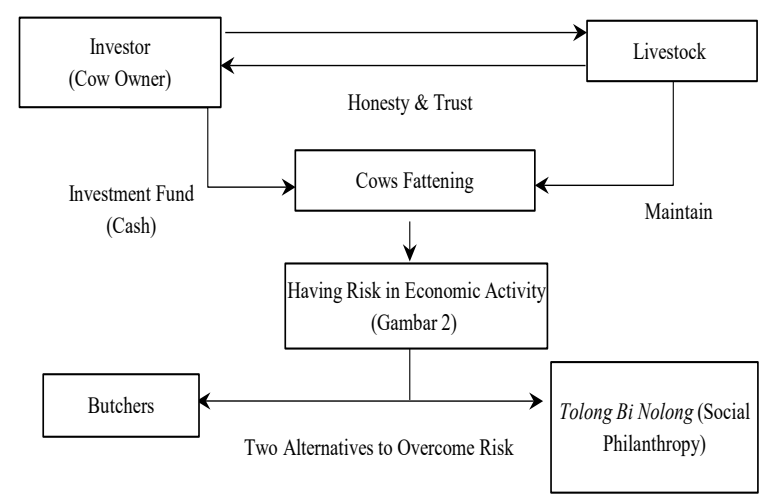

Figure 1. Economic Philanthropy Mechanism in Madurese Cattle Sharing

The cattle sharing program includes the process of beef cattle fattening from large local ruminant animals in Madura-Indonesia. The economic value for beef cattle prices is relatively standard and affordable. The monetary range is between IDR $10,000,000$ and IDR $15,000,000$. The characteristics of shared beef cattle determines the price. Big-sized cows with certain uniqueness are definitely more pricey than the average. The fattening process of beef cattle requires six to twelvemonths period. It depends on the agreement contract between the owners and the sharer. When the contract term is over, the cattle 
sharing between the owner and the sharer takes place. An agreement that does not involve the legal process also happens. Honesty and trust are the foundation of the agreement between two parties. This activity is going on and done hereditary by the ancestors in Indonesia, especially in Madura.

Economic activities are inseparable from the risks that the cattle sharing farmers have to face and take responsibility for. Not to mention, the risk of substantial losses the owners have to bear when the cows die. The stakeholders involved have risk context that fits their role in cattle sharing program. Risk of loss mitigation can be done by having the sick cow diagnosed in the vet. Preventing the risks are performed by preventive healthcare, by feeding the cows with traditional medicine such as turmeric, curcuma aeruginosa (temuireng), curcuma, ginger, aromatic ginger, brown sugar, old coconuts, "Ayam Jago" herbs, free-range chicken eggs, and duck eggs. Accepting the risk of an unhealthy cow is done through a butcher. The risk transfer is done through tolong bi nolong tradition. Based on the schematic, it can be seen in the risk loss mapping in cattle sharing economic activities, as follows:

\begin{tabular}{|c|c|c|c|}
\hline Often & \multirow{2}{*}{ 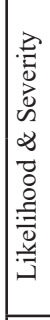 } & $\begin{array}{c}\text { Preventing Risk } \\
\text { Cows are fed with } \\
\text { traditional herbs before } \\
\text { sick }\end{array}$ & $\begin{array}{c}\text { Risk Mitigation } \\
\text { The vet diagnosed the } \\
\text { sick cow }\end{array}$ \\
\hline \multirow[t]{2}{*}{ Seldom } & & $\begin{array}{c}\text { Risk Transfer } \\
\text { (Sick cows could not } \\
\text { be helped) } \\
\text { Solution: tolong bi } \\
\text { nolong }\end{array}$ & $\begin{array}{c}\text { Accepting Risk } \\
\text { Sick cows could not be } \\
\text { helped } \\
\text { Solution: } \text { Sell to } \\
\text { butchers }\end{array}$ \\
\hline & & Small) & Finance \\
\hline
\end{tabular}

Figure 2. Risk Mapping in Cattle Sharing Activity

Based on the figure 2 above, tolong bi nolong tradition works efficiently in minimizing the risk of loss that happens. In the case, the cow of the informant (Pak Ahmad from H. Samian) if the cow is still in good health, the estimated price is around IDR 12,000,000. Ahmad's shared cattle is sick and could not be helped, so he asked the residents to help perform tolong bi nolong in his house. The slaughter was carried out at the moment. The cut cattle weigh around $110 \mathrm{~kg}$, excluding tripe and cow's head, as well as cow bones given freely to residents who helped. The price of fresh meat in the market was around IDR 120,000. The sick cow was valued at IDR 80,000 . The price of the head was IDR 100,000 , while the tripe can reach as high as IDR 150,000 . The total amount of the selling price that the farmer got is IDR $9,050,000$. The loss was as big as IDR 12,000,000 - IDR 9,050,000 equals to IDR $2,950,000$. If the sick cow was cut off by the butcher, the estimated price of the cow was IDR $6,000,000$ to IDR 7,000,000. The loss could reach 50\%: 50\%. Tolong bi nolong was the alternative Ahmad chose to minimize the loss.

\section{Tolong Bi Nolong: Traditional Philanthropy Practices}

The philanthropy development is inseparable from sociology studies that could create the image of corporations in public (Barman, 2017). Philanthropy concept has diverse form from the origin (Daly, 2012). Such as social philanthropy, corporate philanthropy, altruism, giving, and charitable (Adloff, 2009; Barman, 2017; Kolm, 2006; Wuthnow, 1991). The extended meaning of the philanthropy that comes out of the original, in the form of "caring for human life" to the form of "justice and social welfare" whether individuals, organizations, institutions, or corporations. However, philanthropy is still in accordance with the original meaning of an "altruism" for the benefit of others (Kolm, 2006). In broad outline, a concern arises from a joint initiative for collective goals (Daly, 2012).

The definition of modern philanthropy does not change the original form of philanthropy itself (Daly, 2012). Philanthropy as a form of love, care, transfer of economic resources for sustainable social welfare (Kolm, 2006). The definition is still attached to the form of generosity in helping someone or collectively in the socio-cultural or economic context. The meaning of philanthropy remains the same as the original, although it has developed from academic studies such as economics, psychology, and anthropology (Andreoni \& Payne, 2013; Lehmann \& Keller, 2006; Piliavin \& Charng, 1990). This philanthropy study is used in the research to work as academic study in the beginning, to dissect the traditional economic philanthropy values in the Madurese-Indonesian cattle sharing program.

The literal meaning of tolong bi nolong is helping each other. But deeper, tolong bi nolong has a big tendency to socio-cultural values that are a sign of togetherness, cohesiveness, and a strong bond of solidarity between neighbors of Madurese cattle farmers. Culturally, generosity attached to Indonesians dominantly. The concept is inherent in many daily activities. People who do not take part in tolong bi nolong will be the talk of the town. People who do not help provide financial and energy will become a topic among society, so they feel ostracized. These values bond the Madurese to always help their cattle farmer neighbors in need of facing the economic risk in a cattle sharing system. 
The owners who trust the sharer (Madurese cattle farmer) are wisely accepting the fact of the risks. Cow owners do not feel disadvantaged when the cows are died or sick because of financial losses. They feel lucky or "ontong" to find out that tolong bi nolong in Sampang District area is still carried out. The cow owner undeniably will suffer loss, but the high plurality within the community makes him feel surrounded by many relatives. The neighbors gathered to help the cattle farmer in need of help. They call it guyub rukun atong rontong in helping the cow slaughtering process and even the distribution that can be directly sold and also by installment according to the ability of the residents.

Schematically when there is "ajung rojung" carrying out tolong bi nolong, the tradition starts from when the cow is sick and could not be helped or suffering cows. The cattle farmer sharer will directly call the owner and ask to come see the cow immediately. The technology allows people to communicate through phone and save the time. The cow will be slaughtered without the permission of the owner, worrying it might die any time soon. Madurese, especially Sampang, hold tight the Islamic values in slaughtering process. Besides the owner, the cattle farmer will also call the butcher. The butcher holds an important role in saving the risk of loss from the cattle.

Tolong bi nolong mechanism is carried out in groups of their own relatives (tanean lanjeng), but there is also a combination of the residents (nontanean lanjeng). As many as $110 \mathrm{~kg}$ meat were shared among 9 groups of the residents. The average people who help or "atatolong" get $3 \mathrm{~kg}$ and the others $2 \mathrm{~kg}$. If it is illustrated in schematic form, will be as follows:

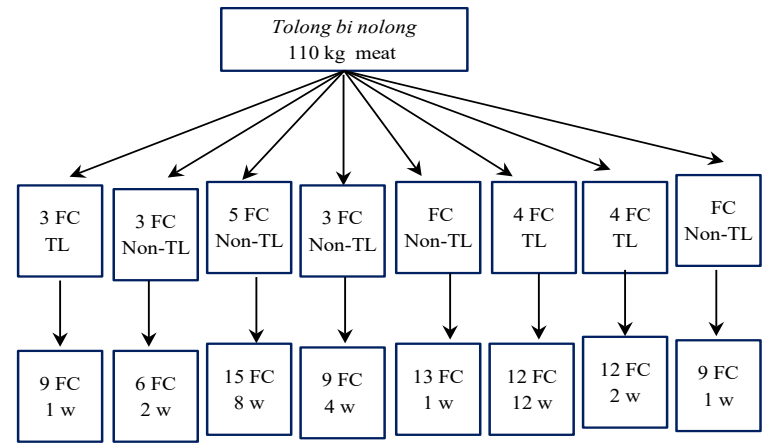

Figure 3. Network of Residents Carrying Out Tolong Bi Nolong Tradition

$\begin{array}{lll}\text { Description: } & & \\ \mathrm{FC} & = & \text { Family Cluster (atatolong) } \\ \mathrm{TL} & = & \text { Nonean Lanjeng } \\ \mathrm{Non}-\mathrm{TL} & = & \text { Kilogram } \\ \mathrm{Kg} & & \begin{array}{l}\text { Week (the time to return the cash to cattle } \\ \mathrm{W}\end{array} \\ & & \text { farmer) }\end{array}$

At the time the cattle rancher had coordinated with the cow owner (spontaneously) and at the same time with a butcher, some residents usually directly carry out the slaughter process. At the time the cow was skinned and cut off, both meat and bones, also the innards cleansing, some residents ask the others to gather in the cattle farmer's house in need of help. They usually come in group to share the cost of the meat. The have will pay cash directly at the same day. Some also pay with debt within a certain period. Usually, "dhaging satompo" (pile of meat) consists of 3-5 kg. It consists of various parts of the cow such as bones, meat, fat and innards. It is usually shared among three to five people. Each resident at least gets $1 \mathrm{~kg}$ and maximum of $2 \mathrm{~kg}$. During the payment process to the cattle farmer (distress) also wait for each other within the cluster to pay together the debt of a pile of meat they share. The residents are used to pay it for a certain period of time between one to three months (the longest period). The processes above are commonly done by the residents of SampangMadura because it could reduce the risk of beef cattle in Madura.

Tolong bi nolong is one of the alternatives to help fellow cattle farmer to ease their burden. Cattle farmers are not only responsible for the moral burden toward the owner, but also to keep the trust between them, to get back the opportunity in the next cattle sharing. The risk of cattle sharing is considered as the common signs that come from The God Almighty. All kind of life will meet an end. The living will die. People can only help to ease each others' burden to live life as cattle farmers like before. Basically, there are two alternatives to reduce the risk of cattle when it could not be helped. First, carry out tolong $b i$ nolong tradition. Second, bring the suffering cattle to the butcher. Each alternative has its own advantages and disadvantages, as follows:

Tolong bi nolong among Madurese means more than a tradition carried out hereditary. This value has attached as a harmony among fellow residents. Economic principles that work in line with culture are part of values that are strictly related to the economic, not only for personal interest, but joint interest. This strong foundation serves as a benchmark for the economic concepts of local communities in Madura. One of them is Mr. Ahmad who acts as the sharer of the beef cattle of H Samian. It once happened while raising cow; the cow had a bloated stomach which interferes the food intakes. Madurese named this "ngangsor", an out of breath condition that interferes with the food intakes causing the cow not being able to eat or stand. The vet had diagnosed the cattle for a day and night, Ahmad gathered his relatives to discuss 
about the cattle further. The agreement came up with the frequently used term "bang tembang sapena mate bango'e sambel liang olok bala tatangga" (it is better to slaughter the cow and invite neighbors than to let it die). At that time H Samian was told that the cow was about to be slaughtered. It was an emergency, without a coordination with the owner, the cow was slaughtered while still alive. Ahmad and his family began to work in his house "bhiddhangan" and served the residents with a cup of tea or coffee. H Samian as the owner of numerous cattle is not responsible to attend the event. This proves the trust H Samian had for Ahmad who keep and feed his cattle wholeheartedly. As the sharer "se-ngoan" Ahmad certainly hold a high sense of trust while keeping and feeding the cattle of H Samian who put trust on him. Social jealousy might happen if $\mathrm{H}$ Samian made an appearance in Ahmad's house. This might cause a gap between the sharer and the owner.

\section{CONCLUSION}

The philanthropic economic activity is a form of Madurese altruism to protect their rights from the cattle farmers and the investors. The local pattern had attached to the economic and social dimensions in daily habits. Beef cattle sharing in Madura contains the traditional philanthropy uniquness of tolong $b i$ nolong. The activities refer to economic custom as a business terminology from profit and loss sharing management based on local pattern value. The economic impact benefits in the risk management borne together. The social aspect affects the helping process whenever risk of loss from cattle sharing happens.

Tolong bi nolong tradition value first occured in West Madura cattle sharing named oanan. Oanan characteristic that underlies the cooperation settlement lies in the honesty integrity known as "Oreng jujur bakal pojur; oreng pojur mate ngonjur". That value accommodates the cattle farmers and the investorsr in profit sharing fattening program of cattle breeding. Economic philanthropy mechanism in Madurese cattle sharing involved tolong bi nolong principles. Tolong bi nolong in risk mapping is the risk of the possibility of rare occurrence with alternative risk transfer losses in cattle sharing activities. In practice, it is mentioned as a local pattern of Madurese which contains the social values of philanthropy.

The schematic practice of tolong bi nolong is done in groups with local community roles known as ajung rojung. The term of clustered residents is tanean lanjeng which is a community of the family. People who are not relatives are not called the tanean lanjeng family. They work hand in hand in groups to help the cattle farmer who are at risk of cattle death. They share the cut meat fairly and according to the ability of each family cluster to help the sharer. Meat is assisted by the surrounding community with financial assistance in order to ease the burden of the farmer at risk of cattle death. Tolong bi nolong practice in cattle sharing activities has been going on since the ancestors and became locality traits and economic custom of the Madurese community.

\section{ACKNOWLEDGMENTS}

I would like to thank the Institute of Research and Community Services at the Trunojoyo University of Madura for providing 2019 research grants. I would also like to thank the following people for helpingwith this research project: the informants and research assistants. Thank you for all the support and assistance.

\section{REFERENCES}

Abida, A. (2016). Analisis Strategi Fundraising Terhadap Peningkatan Pengelolaan ZIS Pada Lembaga Amil Zakat Kabupaten Ponorogo. Kodifikasia, 10, (1), 163-189.

Adloff, F. (2009). What Encourages Charitable Giving and Philanthropy? Ageing and Society, 29, (08), 1185-1205. https://doi. org/10.1017/S0144686X08008295

Adloff, F. (2014). Foundations and The Charisma of Giving: A Historical Sociology of Philanthropy in Germany and the United States. Voluntas. https://doi.org/10.1007/ s11266-014-9508-4

Adloff, F. (2016). Approaching Philanthropy From a Social Theory Perspective. In In The Routledge Companion to Philanthropy, ed. T Jung, SD Phillips, J Harrow,. London: Routledge.

Alexander, V.D. (1996). From philanthropy to Funding : The effects of Corporate and Public Support on American Art Museums. Poetics, 24, 87-129.

Andreoni, J. \& Payne, A. A. (2013). Charitable Giving. In Handbook of Public Economics, 5. Elsevier B.V. https://doi.org/10.1016/B978-0444-53759-1.00001-7

Ang, J. S., Lin, J.W. \& Tyler, F. (1995). Evidence on the Lack of Separation Between Business and Personal Risks Among Small Businesses. Journal of Small Business Finance, 4, (2), 197-210. 
Atika, D.B. (2017). Revitalisasi Peran Karang Taruna Melalui Pemberdayaan SNS (Social Networking Sites) (Studi Pada Karang Taruna Kecamatan Pardasuka Kab. Pringsewu). Jurnal Ilmiah Administrasi Publik Dan Pembangunan, 8, (2), 137-144.

Barman, E. (2016). Caring Capitalism: The Meaning and Measure of Social Value. Cambridge, UK: Cambridge Univ. Pres. https://doi. org/10.1111/1468-4446.12243

Barman, E. (2017). The Social Bases of Philanthropy. Annu. Rev. Sociol., 43, (22), 1-22.20. https:// doi.org/10.1146/annurev-soc-060116CITATIONS

Bowen, J.R. (1986). On the Political Construction of Tradition : Gotong Royong in Indonesia. Journal of Asian Studies, 45, (3), 545-561.

BPS-Statistic Indonesia. (2018). Jawa Timur Province in Figures 2018. BPS Provinsi Jawa Timur.

Charities Aid Foundation. (2019). CAF World Giving Index 10th Edition. In Charities Aid Foundation (Issue October). https://www. cafonline.org/about-us/publications/2019publications/caf-world-giving-index-10thedition

Collins, J. (2013). A Study of Religiosity and Conservatismin Relation to Social Value Orientation and Philanthropy. Modern Psychological Studies, 18, (2), 10.

Daly, S. (2012). Philanthropy as an Essentially Contested Concept. 23, (3), 535-557. https:// doi.org/10.1007/s11266-011-9213-5

Djaelani, S., Widiati, R., \& Santosa, K. A. (2009). Pemberdayaan Masyarakat Melalui Proyek Gaduhan Sapi Potong Di Kecamatan Oba Tengah dan Oba Utara, Tidore Kepulauan, Maluku Utara. Buletin Peternakan, 33, (1), 40-48.

Edmondson, V.C. \& Carroll, A.B. (1999). Giving Back: An Examination of The Philanthropic Motivations, Orientations and Activities of Large Black-Owned Businesses. Journal of Business Ethics, 19, (2), 171-179. https://doi. org/10.1023/A:1005993925597

Efendy, J. (2016). Profiles of Beef Cattle Breeding Based on Local Resources in Sumenep Regency (A case study at KTT Sumber Hasil Talang Village, Serongi District, Sumenep Regency, East Java). JITP, 5, (1), 27-31.
Fauzia, A. (2017). Islamic philanthropy in Indonesia: Modernization, islamization, and social justice. Austrian Journal of South-East Asian Studies, 10, (2), 223-236.

Gautier, A. \& Pache, A.C. (2013). Research on Corporate Philanthropy: A Review and Assessment. Journal of Business Ethics, 126, (3), 343-369. https://doi.org/10.1007/s10551013-1969-7

Hammack, D. C., \& Anheier, H. K. (2013). A Versatile American institution. The Changing Ideals and Realities of Philanthropic Voundations. Washington, DC: Brookings Institution.

Hartatik, T., Mahardika, D.A., Widi, T.S.M. \& Baliarti, E. (2009). Karakteristik dan Kinerja Induk Sapi Silangan Limousin-Madura dan Madura Di Kabupaten Sumenep dan Pamekasan. Buletin Peternakan, 33, (3), 143147.

Helms, S.E. \& Thornton, J.P. (2012). The Influence of Religiosity on Charitable Behavior: A COPPS Investigation. Journal of Socio-Economics, 41, (4), 373-383. https://doi.org/10.1016/j. socec.2012.04.003

Hoyt, R.E. \& Liebenberg, A.P. (2011). The Value of Enterprise Risk Management. The Journal of Risk and Insurance, 78, (4), 795-822. https:// doi.org/10.1111/j.1539-6975.2011.01413.x

Ibrahim, J.T., Sutawi. \& Jayus. (2013). Analisis Kinerja Program Pengembangan Usaha Sapi Potong Pola Gaduhan Sistem Revolving. Agrise, XIII, (2), 163-174.

Jusuf, C. (2007). Filantropi Modern Untuk Pembangunan Sosial. Jurnal Penelitian Dan Pengembangan Kesejahteraan Sosial, 12, (1), 74-84.

Kantabutra, S. \& Suriyankietkaew, S. (2019). Sustainable Leadership : Rhineland Practices at a Thai small Enterprise Sustainable Leadership: Rhineland practices at a Thai Small Enterprise. J. Entrepreneurship and Small Business, 19, (01), 76-94. https://doi. org/10.1504/IJESB.2013.054313

Kolm, S. (2006). Handbook ofthe Economics ofGiving, Altruism and Reciprocity, 1, (06). Elsevier B.V. https://doi.org/10.1016/S15740714(06)01001-3

Kosim, M. (2007). Kerapan Sapi; “ Pesta Rakyat Madura" (Perspektif Historis-Normatif). Karsa, 11, (1), 68-76. 
Kumar, S., Kwong, A. \& Misra, C. (2010). Risk mitigation in offshoring of business operations. https://doi.org/10.1108/17410380910953711

Kurniawan, P. (2016). Memahami Pertautan Agama dan Budaya Studi Terhadap Tradisi MarpegePege di Batak Angkola. Yurisprudentia, 2, (2), 35-53. http://jurnal.iain-padangsidimpuan. ac.id/index.php/yurisprudentia/article/ view/670

Kutsiyah, F. (2018). "Skenario" Madura Sebagai Pulau Sapi. MADURANCH, 3, (1), 34- 46.

Kutsiyah, F. (2019). Development of Rural Tourism Destination and Creative Economic Base on Sapi Sonok Culture in Madura Island. Urnal Ekonomi Pertanian Dan Agribisnis (Jepa), 3, (3), 586-599.

Latief, H. (2010). Transforming the Culture of Giving in Indonesia: The Muslim Middle Class, Crisis and Philanthropy. Nanzan University Asia-Pacific Research Center, 11, (11), Jepang: Nanzan University.

Lavington, F. (1925). An Approach to the Theory of Business Risks. The Economic Journal, 35, (138), 186-199.

Lehmann, L. \& Keller, L. (2006). The Evolution of Cooperation and Altruism-- a General Framework and A Classification of Models. $J$. Evol. Bio, 19, 1365-76.

Lipset, S. M. (1996). Lipset SM. 1996. American Exceptionalism: A Double-Edged Sword. In New York: WWNorton. https://doi. org/10.4324/9781315097350

Makhrus. (2014). Aktivisme Pemberdayaan Masyarakat dan Institusionalisasi Filantropi Islam di Indonesia. Islamadina, 13, (2), 2344.

Malta. (2016). Factors Related to Farmer Independence in Decision Making on Sustainable Agribusiness (A Case Study of farmers in Sukaharja Village, Bogor Regency). Sosiohumaniora, 18, (2), 118-124. https://doi. org/https://doi.org/10.24198/sosiohumaniora. v18i2.9945

Marrewijk, M. Van. (2003). Concepts and Definitions of CSR and Corporate Sustainability: Between Agency and Communion. Journal of Business Ethics, 44, 95-105.

Mattis, J.S., Jagers, R.J., Hatcher, C.A., Lawhon, G.D., Murphy, E.J. \& Murray, Y.F. (2000).
Religiosity, Volunteerism, and Community Involvement Among African American Men: An Exploratory Analysis. Journal of Community Psychology, 28, (4), 391-406. https://doi.org/10.1002/1520$6629(200007) 28: 4<391::$ A I D JCOP2>3.0.CO;2-A

McGoey, L. (2015). No Such Thing as a Free Gift: The Gates Foundation and the Price of Philanthropy. London: Verso Books.

Monroe, R. (1996). The Heart of Altruism Perceptions Of A Common Humanity Kristen.

Nasrullah, A. (2015). Pengelolaan Dana Filantropi Untuk Pemberdayaan Pendidikan Anak Dhuafa (Studi Kasus Pada BMH Cabang Malang Jawa Timur). Hunafa Jurnal Studi Islamika, 12, (1), 1-18.

Novra, A. (2015). Subsidi subsidi Bunga Modal Yang Diterima Rumah Tangga Peternak Sapi Binaan Program CSR (Corporate Social Responsibilty) Petrochina Jabung Ltd. Agriekonomika, 4, (2), 122-131.

Nurgiartiningsih, V.M. (2011). Peta Potensi Genetik Sapi Madura Murni di Empat Kabupaten di Madura. J. Ternak Tropika, 12, (2), 23-32.

Nurhayati, A., Lili, W., Herawati, T. \& Riyantini, I. (2016). Derivatif Analysis of Economic and Social Aspect of Added Value Minapadi ( Paddy-Fish Integrative Farming ) a Case Study in the Village of Sagaracipta Ciparay Sub District. Aquatic Procedia, 7, 12-18. https://doi.org/10.1016/j.aqpro.2016.07.002

Piliavin, J. \& Charng, H. (1990). Altruism: a Review of Recent Theory and Research. Annu. Rev. Sociol, 16, 27-65.

Prananingrum, D.H. (2018). Filantropi Dan Pelayanan Rumah Sakit Berbasis Gerejawi Dalam Perspektif Hukum. Refleksi Hukum Jurnal Ilmu Hukum, 3, (1), 17-32.

Prasetyo, Y.E., Agustina, W. \& Salim, T. (2015). Beef Cattle Traditional Agribussines Practices in Indonesia: Special Case in Subang, West Java. Third International Conference on Creativity and Innovations at (for/from/with) Grassroots [ICCIG], 1-12.

Prasetyono, P. \& Rakhmawati, Y. (2019). Gaduhan : Madurese Traditional Cattle Sharing Program in Economic and Social Perspective. Advances in Social Science, Education and Humanities Research, 363, (Icss), 24-27. 
Prince, R.A., File, K.M. \& Gillespie, J.E. (1993). Philanthropic Styles. Nonprofit Management and Leadership, 3, (3), 255-268. https://doi. org/10.1002/nml.4130030304

Reid, K., Flowers, P. \& Larkin, M. (2005). Exploring Lived Experience: An introduction to Interpretative Phenomenological Analysis. The Psychologist, 18, 20-23.

Riszqina, R., Isbandi, I., Rianto, E. \& Santoso, S.I. (2014). The Analysis of Factors Affecting the Performance and Benefit of Karapan (Racing) Cattle Business in Madura Island, East Java, Indonesia. Journal of the Indonesian Tropical Animal Agriculture, 39, (1), 65-72. https:// doi.org/10.14710/jitaa.39.1.65-72

Sakni, A. S. (2013). Konsep Ekonomi Islam Dalam Mengentaskan Kesenjangan Sosial: Studi atas Wacana Filantropi Islam dalam Syari'at Wakaf.Jurnal Ilmu Agama, XIV, (1), 151-166.

Sarasvathy, D. K., Simon, H. A., \& Lave, L. (1998). Perceiving and Managing Business Risks: Differences Between Entrepreneurs and Bankers. Journal of Economic Behavior \& Organization, 33, 207-225.

Scott, J. E. (2004). Measuring Dimensions of Perceived E-business Risks. Information Systems and E-Business Management, 2, (1), 31-55. https://doi.org/10.1007/s10257-0030026-y

Scott, N., \& Seglow, J. (2007). Altruism. Berkshire: Open University Press.

Sherman, W. R. (2012). The Triple Bottom Line: The Reporting Of " Doing Well " \& " Doing Good". The Journal of Applied Business Research, 28, (4), 673-682.

Simpson, B., \& Willer, R. (2015). Beyond Altruism: Sociological Foundations of Cooperation and Prosocial Behavior. Annual Review of Sociology, 41,(1), 43-63. https://doi. org/10.1146/annurev-soc-073014-112242

Sitorus, M. (2013). Peran Komunikasi dan Kontribusi Filantropi dalam Pasca Darurat Bencana. JIPSI: Jurnal Ilmiah Ilmu Politik Dan Komunikasi, 1, (23).

Smith,J.A.,Flowers,P.\&Larkin,M.(2011).Interpretative Phenomenological Analysis Theory, Method and Research. London: SAGE Publications. https://doi.org/10.1163/156916211X599762

Suartana, I.W., \& Jati, I.K. (2017). Risk Based Internal Audit Based on Culture (Case Study at LPD Desa Adat Pecatu in Bali). Risk, 8, (18), 190-200.

Suharto, E. (2015). Peran Perlindungan Sosial Dalam Mengatasi Kemiskinan Di Indonesia: Studi Kasus Program Keluarga Harapan. Sosiohumaniora, 17, (1), 22-28. https://doi. org/10.24198/sosiohumaniora.v17i1.5668

Sulaiman, A. I., Chusmeru. \& Masrukin. (2018). Strategy of Cooperative Islamic Boarding School as Economic Empowerment Community. Jurnal Inferensi, 12, (1), 25-44.

Sumrahadi, A. \& Suryandari, R.Y. (2013). Praktik Filantropi Sosial Bagi Pembangunan Aktiviti Seni dan Budaya: Suatu Wacana. Geografia: Malaysian Journal of Society and Space, 9, (3), 95-106.

Tamim, I.H. (2016). Filantropi dan Pembangunan. Community Development Journal, 1, (1), 121-136.

Tawaf, R. (2018). Analisis Usaha Pembiakan Sapi Potong Pola Kemitraan Antara Korporasi Dengan Peternak Rakyat. Sosiohumaniora, 20, (1), 45-56. https://doi.org/https://doi. org/10.24198/sosiohumaniora.v20i1.16141

Tilcsik, A. \& Marquis, C. (2013). Punctuated Generosity: How Mega-events and Natural Disasters Affect Corporate philanthropy in U.S. Communities. Administrative Science Quarterly, 58, (1), 111-148. https://doi. org/10.1177/0001839213475800

Wu, D., Olson, D. L. \& Dolgui, A. (2015). Author 's Accepted Manuscript. Omega. https://doi. org/10.1016/j.omega.2015.04.011

Wüllenweber, K., Jahner, S. \& Krcmar, H. (2008). Relational Risk Mitigation: The Relationship Approach to Mitigating Risks in Business Process Outsourcing. Proceedings of the Annual Hawaii International Conference on System Sciences, 1-10. https://doi. org/10.1109/HICSS.2008.371

Wuthnow, R. (1991). Acts of Compassion. In Princeton, NJ: Princeton Univ. Press. 